\title{
Coda: Exploring Male Depression and the Stigma Associated with Depression
}

\author{
Sheena Sugiarto \\ English for Creative Industry, Faculty of Languages and Literature, Petra Christian University, \\ Siwalankerto 121-131, Surabaya 60236, Indonesia. \\ E-mail: sheena.sugiarto@gmail.com
}

\begin{abstract}
This creative thesis aims to show depressive symptoms in men, the stigma associated with depression, and the way stigma impacts depressed individuals by means of a screenplay. Using drama as the genre and psychological drama as the sub-genre, I exploit the emotional strain of the main character to show the struggles of male depression as well as the brutal consequences of stigma. The screenplay, titled Coda, follows Arya, a boy who struggles with depression and stigma associated with depression. As the story progresses, Arya's mental health condition increasingly declines. Arya exhibits depressive symptoms although they are not typically recognized as depression. These include frequent irritability and inappropriate anger, escapists behavior, physical symptoms, problems with drug use, and risky behavior. In addition to that, Arya also experiences personal stigma from his family, which gradually affects their relationship and ultimately leads him to impulsively commit suicide.
\end{abstract}

Keywords: Male depression, stigma, impact

\section{INTRODUCTION}

During my studies in English for Creative Industry major, I involved myself in many activities. I was active in multiple organization and club events, from theatrical performance to film production. Eventually, I found my hidden love for screenplay writing and filmmaking, and even took several classes to learn more about it. In spite of my limited skills and knowledge of filmmaking, I am determined to create a meaningful screenplay for my creative thesis.

According to Moreno and Tuxford, author of The Pocket Screenwriting Guide: 120 Tips for Getting to FADE OUT and a founding member of the The Writer's Store's reading and coaching programs, a screenplay is a blueprint for the film it will one day become and should consist of aural, visual, behavioral, and lingual elements (Moreno \& Tuxford, n.d.; Spierling, 2008 , p. 211). In other words, a screenplay is an array of guidelines to help the production crew members do their job properly, which determines the outcome of the film. Making a film without a screenplay is like building a house without a blueprint; it will probably result in weak structures that call for reconstructions.

There are many reasons as to why I chose screenplay as my creative thesis. A screenplay is essentially a script for film or television show. As such, a screenplay can provide strong visual designs that cannot be achieved using any other creative works. After all, "film is largely a visual medium, so it's often wise to play to its strengths" (McGrail, n.d., Externalize the Internal section). Since it allows me to visualize my ideas better, the overall writing process becomes easier. Furthermore, due to its visual nature, film can deliver issue and message quicker than written words, making it a great media to reach and inform a vast audience. In fact, "motion pictures are increasingly becoming the primary modes of spreading information and educating audiences" (Drucker, 2012, para. 1).

Aside from its visual appeal, film also has aural traction. According to Cohen (2001), a leading expert in psychology of music, sound has been present in film since its earliest days. Even silent films have music to mask noises and provide additional context (Cohen, 2001). In 
its progression, sound has become such a big part of film that it may just be as important as the image on screen (The Los Angeles Film School, 2017). Nowadays, filmmakers use sound for various reasons such as heightening the sense of reality, setting the mood and tone of scenes, and intensifying suspense. Sound can also take on different forms: human voice, sound effect, and music (The Los Angeles Film School, 2017). For my screenplay, I will use all of these forms, with music being predominant due to its close correlation with dance, an underlying subject in this project. This will allow me to induce certain moods in the scenes and enhance emotion, especially during the dance portion of the story.

Ironically, the absence of sound in film does not always prompt failure; rather, it is a tool that, if used correctly, can bring the story to life (Harriott, 2017). Of course, this does not mean that a good film should be entirely silent, but just enough to serve its purpose. For my screenplay, I want to create a dynamic using sound and silence to further refine audience experience.

That being said, a screenplay is essential for the issue I am raising since a delicate topic such as depression will require more than verbal description. Instead, the audiovisual representation in a screenplay will help render the issue in a more profound way to the audience.

On top of that, the film industry is rapidly thriving in this modern era. As a matter of fact, the global box office revenue reached approximately 38 billion U.S. dollars in 2016 and is predicted to increase up to 50 billion U.S. dollars by 2020 (Watson, 2018). In addition to that, Sasongko, founder and CEO of Visinema Pictures, stated that the Indonesian box office revenue reached 392 million U.S. dollars in 2018, a 20-30\% climb from previous years (Dwinanda, 2019). This is evidence that the film industry is becoming even more popular. Aside from the box office, film festivals have also gained major popularity. For many years, there have been thousands of film festivals listed all across the globe to showcase new talents and promote filmmaking in general (Follows, 2013). Seeing that the marketplace for film is very wide, a screenplay would be the most appropriate form of creative work for me.

Timewise, there are two types of screenplay: short film screenplay and feature film screenplay. A short film, according to The Academy of Motion Picture Arts and Sciences (as cited in Miyamoto, 2017), has a running time of 40 minutes or less, including all credits. As a rule of thumb, each script page equals one minute of screen time. Therefore, a short script should have approximately 40 pages. Feature scripts, on the other hand, run anywhere from 80 to 130 pages, according to the general guidelines and expectations of the film industry (Miyamoto, 2017). For my screenplay, I will write a feature script to deal with the delicate topic of depression.

The genre I have chosen for my screenplay is drama. Drama in film is a genre that relies on the emotional and relational development of realistic characters which aims to tell an honest story of human struggles (Buffam, 2011). This genre is ideal for my screenplay because I want to portray my character's journey throughout the story and capture the depression aspect in a way that will be readily received by the audience, that is through sentimental values. I will utilize this genre to exploit my main character's internal and external conflicts. In addition, I want to use a subgenre of drama, psychological drama, or also known as psycho-drama, which puts attention to mental illness struggles (McKee, 1997). I will use this genre as I want my story to revolve around my main character's struggle with depression.

In this creative thesis, I want to explore depression because it is a very concerning issue, especially in culturally conservative countries like Indonesia, where only a small percentage of people with mental illness seek treatment (Siauw, 2018). Like many other mental illnesses, the biggest concerns with depression are the stigma. According to Beyondblue (2015), most people 
Sugiarto: Coda: Exploring Male Depression and the Stigma Associated with Depression

with depression experience stigma related to their mental health condition. The type(s) of stigma experienced may vary depending on the condition, age, gender, and culture. This can greatly affect their personal relationship and kill their impulse to seek treatment (Beyondblue, 2015). That being so, I want my screenplay to help more people understand about depression, therefore reducing stigma surrounding it. In addition to that, I want to delve deeper into the relation between gender and depression, specifically with the male gender, as it provides a unique angle to "understand the causes of depression in general" (Nolen-Hoeksema, 2001, p. 176).

Clinical depression or also known as major depressive disorder is a mood disorder where an individual feel sad, empty, and hopeless most of the times. This may cause said individual to experience a change in eating and sleeping pattern, as well as loss of interest, fatigue, and focus (American Psychiatric Association, 2013). Depression is a common illness worldwide, with more than 300 million people affected (World Health Organization, 2020), and even with the amount of research and information that we have, the depression rates continue to rise dramatically. In fact, diagnosis of major depression climbed up by 33 percent in just under five years (Blue Cross Blue Shield, 2018). In Indonesia alone, the prevalence rate of depression is $3.7 \%$ of the population, which equals to over nine million people, not including unreported cases (World Health Organization, 2017).

Gender plays a very interesting role in mental illness. In fact, gender differences affect prevalence rates in many mental problems, including depression (Ryba \& Hopko, 2012).

According to Nolen-Hoeksema (2001), women are twice more likely to develop depression than men. However, research suggests that male depression often goes undiagnosed, which is why this issue needs more attention (Mayo Clinic, 2019).

All things considered, my screenplay follows Arya, a depressed teenager who wants to pursue a career as a dancer. However, after his cousin, Andhika, got accepted into medical school, he is pressured by his father to follow Andhika's footsteps, leaving his dreams behind and causing him to fall deeper into depression.

\section{OUTLINE OF THE CREATIVE WORK}

Considering that screenplay writing is a design, screenplay writing process follows some design steps. It starts with the foundations which are the premise and design principle. The next step is building the story with a pitch, which is then to be developed into a synopsis. From there, a step outline is constructed, which will finally become the skeleton of the treatment and screenplay. Apart from the outline, I also need to develop the characters and basic conflicts of the screenplay (see the full screenplay in my thesis: Coda: Exploring Male Depression and the Stigma Associated with Depression).

\section{Premise and Design Principle}

Considering that my topic is male depression and stigma associated with depression, I will implement a premise and design principle as below.

\section{Premise}

A teenage boy who struggles with depression finally reaches his breaking limit after his father, Satria, forbids him from pursuing his lifelong dream of becoming a dancer.

\section{Design Principle}


I want to start the screenplay with Arya's dance scene, which will also appear in the ending scene. This will bring the story to a full circle. Since Arya's depression is repressed, I want to introduce an event that will trigger him to express this side of him early on in the story. The event is the arrival of Arya's cousin whom Arya's father favors more than him. As the story goes on, Arya will receive more and more pressure to be more like his cousin and will gradually show more depressive symptoms. During the climax, the scene will constantly switch between Arya's dance, which is a figment of his imagination, and his suicide. The dance symbolizes what his life would be like if he did not commit suicide. Therefore, these constant changes represent his life and death

\section{Pitch}

1. Arya, a depressed male teenager, wants to pursue a higher education in dancing.

2. His father forbids him from pursuing dance and forces him to study business instead, which drives him even deeper into depression.

3. Arya commits suicide and passes away.

\section{Synopsis}

Arya is a teenager who quietly struggles with depression. However, when his cousin comes to live with him, problems start to unravel. As his father pressures him to be more like his cousin, Arya gradually becomes more depressed. Things get out of hand when his father forbids him from pursuing the only thing he loved to do: dance. Having his one passion brought to a halt led Arya to committing suicide.

\section{Step Outline}

1. Arya dances on the stage and falls.

2. Satria wakes Arya up.

3. Arya washes up.

4. Arya and Satria pray together.

5. Arya asks Satria to buy him more anti-depressants and Satria dismisses Arya and his problem. Afterwards, Satria tells Arya that Andhika will live with them soon. The two get into a fight. Arya then leaves the room.

6. Arya looks up about higher education in dancing.

7. Arya and Satria are having dinner together. Satria tells Arya when Andhika is arriving. Arya is displeased.

8. Andhika arrives at the house. Satria welcomes him into the house and makes Arya carry Andhika's luggage to his bedroom.

9. Andhika and Satria are talking in the living room. Arya joins them. They talk about university. Arya tells Satria that he wants to pursue a higher education in dancing. Arya and Satria get into a fight.

10. Arya sulks in his bedroom and has a flashback about his mom.

11. Andhika asks Arya to pray together. Arya tells him that he is not coming.

12. Andhika and Satria Prays together.

13. Arya is stressing out about his application to the university. He takes an antidepressant pill.

14. Satria and Andhika have dinner together while Arya stays in his bedroom.

15. Andhika sneaks in some buns for Arya. They get into a fight but then makes up. Arya tells Andhika about his passion in dancing. Andhika admits to Arya that he does not want to be a doctor. 
Sugiarto: Coda: Exploring Male Depression and the Stigma Associated with Depression

16. Arya and Andhika makes an agreement: Arya has to submit his application form to Institut Kesenian Indonesia and Andhika has to tell his parents that he does not want to be a doctor. They play rock, paper, scissors, to decide who goes first. Arya loses.

17. Arya submits his application form and worries about his audition.

18. Andhika helps Arya sneak out at night so that he can practice for his audition in the salat room.

19. Arya is making progress in preparing for his audition.

20. Satria catches Arya practicing late at night and scolds him.

21. Arya feels hurt by Satria's words.

22. At lunch, Arya tells Andhika that he is quitting.

23. Satria asks to talk to Arya privately. He wants Arya to apply to Universitas Mercu Buana and take the business major.

24. After lunch, Arya tells Andhika about his talk with Satria.

25. Arya gives up and follows Satria's wishes and orders.

26. Concerned about Arya, Andhika encourages Arya to rethink his decision. He tells Arya that he will follow through their agreement and tell his parents that he does not want to be a doctor. In turn, he wants Arya to keep pursuing dance and participate in the audition.

27. Andhika, Arya, and Satria pick Andhika's parents up at the airport.

28. The five of them have lunch, during which Andhika fails to tell the truth.

29. Later in the evening, Andhika's parents come over at the house. The five of them have a conversation. Andhika admits to his parents that he does not want to be a doctor. Andhika's mother is furious. Everyone becomes tense. Arya and his father also have a fight.

30. Andhika's mother asks Andhika to pack and leave. They go to a hotel.

31. Andhika calls Arya, which wakes him up from a nightmare. He encourages Arya to go to his audition. Arya is unsure because he has to go to his entrance exam at the same time as his audition.

32. Andhika comes over to the house.

33. Arya tells Satria that he wants to go to his audition. They get into a fight.

34. Arya locks himself in his bedroom.

35. Arya commits suicide.

\section{Main Characters}

1. Arya Adipramana, 18 years old, male, is the only child of Satria Adipramana and Lestari Indriati. As a child, he was very close to his mother, who was a dance teacher. He loved tagging along with her to her studio where he could watch people dance. He always mesmerized by dance and eventually took on his mother's passion in dancing. She was his hero and role model. Naturally, he became utterly devastated when she fell ill and passed away. Being left with an emotionally distant father was very hard on the young boy and he became a difficult child. However, his father was not pleased by his acting out nor was he fond of his sensitive nature. His father sternly taught him to be mature and independent. Arya eventually complied and repress his hatred towards his father. As time went on, Arya became more and more lonesome and quiet. He shut himself off from his family, especially his father. He has never had many friends because he is not very sociable. As a teenager, he is very bitter and cold due to his suppressed anger.

2. Satria Adipramana, 52 years old, male, is the typical upholder of gender stereotype. His conservative and old-fashioned ideals made him an emotionally distant father. Not only does he spend most of his time working, but he also forces his ideals on his son. He wants Arya to be tough, strong, and dependable and pressures him to be that way. When he found out that his son wanted to pursue dancing, he was furious. He strongly disapproves of his son's passion, which in his opinion is too feminine. Instead, he wants Arya to follow Andhika's footsteps in choosing a career path he believes is worthy of praise. 
3. Andhika Daniswara, 18 years, male is a bright intelligent young man from a rich family. He is confident, popular, kind, and modest. He is the ideal son any parents would want. Satria feels this way towards Andhika and wishes that Arya be more like him. Because of that, Arya may feel rivaled and overshadowed by him. However, Andhika does not think of Arya as a rival. He actually enjoys hanging out with Arya as cousins would. In fact, Andhika is more supportive of Arya and his passion than Satria.

\section{Conflict}

My screenplay will present two types of conflict. The first one is man versus self, which means that the main character has "internal issues that affect their actions, motivations and interactions with other characters" (Shanbhogue-Arvind, 2013, Man Versus Self section). This will be shown by Arya's struggle with himself and his depression. The second conflict is man versus man, where the main characters oppose or are opposed by "the actions, reactions, motivations of another character" (Shanbhogue-Arvind, 2013, Man Versus Man section). This will be shown by the tension and conflicts between Arya and his father.

\section{Treatment}

Arya dances on the stage and falls. Satria wakes Arya up from his dreams. Arya washes up. Soon after, Arya and Satria pray together. A moment later, Arya asks Satria to buy him more anti-depressants and Satria dismisses Arya and his problem. Afterwards, Satria tells Arya that Andhika will live with them soon, a news which upsets him. The two get into a fight. Arya then leaves the room. He looks up about higher education in dancing.

In the evening, when Arya and Satria are having dinner together, Satria tells Arya when Andhika is arriving. Arya is displeased. A week later, Andhika arrives at the house. Satria welcomes him into the house and makes Arya carry Andhika's luggage to his bedroom. Andhika and Satria are talking in the living room. Arya joins them. They talk about university. Arya tells Satria that he wants to pursue a higher education in dancing. It led them into a fight.

Arya sulks in his bedroom and has a flashback about his mom. Andhika asks Arya to pray together. Arya tells him that he is not coming. Andhika and Satria Prays together. Arya is stressing out about his application to the university. He takes an antidepressant pill. After the prayer, Satria and Andhika have dinner together while Arya stays in his bedroom. Andhika sneaks in some buns for Arya.

When they are together in Arya's room, they get into a fight but then makes up. Arya tells Andhika about his passion in dancing. Andhika admits to Arya that he does not want to be a doctor. Arya and Andhika makes an agreement: Arya has to submit his application form to Institut Kesenian Indonesia and Andhika has to tell his parents that he does not want to be a doctor. They play rock, paper, scissors, to decide who goes first. Arya loses.

Arya submits his application form and worries about his audition. Andhika helps Arya sneak out at night so that he can practice for his audition in the salat room. Arya is making progress in preparing for his audition. Satria catches Arya practicing late at night and scolds him. Arya feels hurt by Satria's words. At lunch, Arya tells Andhika that he is quitting. Satria walks in and has a private talk with Arya. He wants Arya to apply to Universitas Mercu Buana and take the business major.

After lunch, Arya tells Andhika about his talk with Satria. Arya gives up and follows Satria's wishes and orders. Concerned about Arya, Andhika encourages Arya to rethink his 
Sugiarto: Coda: Exploring Male Depression and the Stigma Associated with Depression

decision. He tells Arya that he will follow through their agreement and tell his parents that he does not want to be a doctor. In turn, he wants Arya to keep pursuing dance and participate in the audition.

The next weekend, Andhika, Arya, and Satria pick Andhika's parents up at the airport. The five of them have lunch, during which Andhika fails to tell the truth.

Later in the evening, Andhika's parents come over at the house. The five of them have a conversation. Andhika admits to his parents that he does not want to be a doctor. Andhika's mother, Fara, is furious. Everyone becomes tense. Arya and his father also have a fight. Andhika's mother asks Andhika to pack and leave. They go to a hotel.

A few weeks later, Andhika calls Arya, which wakes him up from a nightmare. He encourages Arya to go to his audition. Arya is unsure because he has to go to his entrance exam at the same time as his audition.

At the entrance exam/audition day, Andhika comes over to the house. Arya tells Satria that he wants to go to his audition. They get into a fight. Arya locks himself in his bedroom. In the end, Arya commits suicide.

\section{CONCLUSION}

In this section, I would like to conclude and restate the purpose of the creative work as well as discuss how I brought them to light in my screenplay.

The first purpose of this screenplay is to show depressive symptoms in men. Since depression symptoms occur differently in men, it is important to highlight how they display their depression. In Coda, Arya exhibits various patterns of behavior that indicate he was depressed. His frequent irritability and inappropriate anger, for instance, comes through very strongly. Furthermore, he spends a lot of time studying and dancing to escape facing unpleasant reality. He also experiences physical symptoms in the form of pain and headaches and often abuses drugs, namely, Fluoxetine, a common antidepressant, to relieve his pain. One last symptom that Arya shows is his risky behavior, which ultimately leads to his suicide.

In addition to that, Coda demonstrates one of several types of stigma associated with depression, which is personal stigma. This is shown by the way Satria and Fara treated Arya. Throughout the screenplay, Satria dismisses Arya's depression multiple times, calling it a 'weakness' instead of acknowledging his depression as a real illness. On top of that, Fara is prejudiced against Arya. She perceives him as a dangerous person because of his mental health condition. Subsequently, Fara also discriminates against Arya by asking Andhika to avoid him. These altogether comprise the three components of stigma: ignorance or misinformation, prejudice, and discrimination.

Last but not least, this screenplay shows how stigma can affect depressed individuals. The impacts of stigma associated with depression can be substantial, especially towards personal relationships. This can be seen from the tension between Arya and his family, especially Satria and Fara, the source of stigma in Arya's case. Furthermore, the stigma Arya experiences makes him feel so hopeless and ashamed that he decides to take his own life. Unfortunately, this drastic measure mirrors real life events, especially with men as they tend to take impulsive actions. 


\section{REFERENCES}

American Psychiatric Association. (2013). Diagnostic and statistical manual of mental disorders (5th ed.). Arlington, VA: American Psychiatric Association.

Beyondblue. (2015, August). Stigma and discrimination associated with depression and anxiety. Retrieved from https://www.beyondblue.org.au/docs/default-source/policysubmissions/stigma-and-discrimination-associated-with-depression-and-anxiety.pdf Blue Cross Blue Shield. (2018, May). Major depression: The impact on overall health. Retrieved from https://www.bcbs.com/sites/default/files/file-attachments/health-ofamerica-report/HoA_Major_Depression_Report.pdf

Buffam, N. (2011, March 14). Drama. Retrieved from https://thescriptlab.com/screenplay/genre/952-drama/

Cohen, A. J. (2001). Music as a source of emotion in film. In P. N. Juslin \& J. A. Sloboda (Eds.), Music and Emotion: Theory and Research (1st ed., pp. 249-272). Retrieved from https://rhythmcoglab.coursepress.yale.edu/wp-content/uploads/sites/5/2014/10/Music-asa-Source-of-Emotion-In-Film.pdf

Drucker, J. R. (2012, November 9). Watching, not reading. Retrieved from https://www.thecrimson.com/article/2012/11/9/movies-books-harvard/

Dwinanda, R. (2019, July 10). Pendapatan industri perfilman Indonesia merangkak naik. Retrieved from https://republika.co.id/berita/pudmnu414/pendapatan-industri-perfilmanindonesia-merangkak-naik

Follows, S. (2013, August 19). How many film festivals are there in the world? Retrieved from https://stephenfollows.com/many-film-festivals-are-in-the-world/

Harriot, M. (2017, February 2). Silence and why it's important in film. Retrieved from https://www.ecgprod.com/silence-and-why-its-important-in-film/

Mayo Clinic. (2019, May 21). Male depression: Understanding the issues. Retrieved from https://www.mayoclinic.org/diseases-conditions/depression/in-depth/male-depression/art20046216

McGrail, L. (n.d.). What visual storytelling looks like in a screenplay. Retrieved from https://www.lightsfilmschool.com/blog/what-visual-storytelling-looks-like-in-ascreenplay-aes

McKee, R. (1997). Story: Substance, Structure, Style and the Principles of Screenwriting (1st ed.). New York, NY: HarperCollins.

Miyamoto, K. (2017, October 12). 3 eye-opening differences between short and feature scripts. Retrieved from https://screencraft.org/2017/10/12/3-major-differences-short-and-featurescripts/

Moreno, M. O., \& Tuxford, K. (n.d.). How to write a screenplay: Script writing example \& screenwriting tips. Retrieved September 4, 2019, from https://www.writersstore.com/how-to-write-a-screenplay-a-guide-to-scriptwriting/

Nolen-Hoeksema, S. (2001). Gender Differences in Depression. Current Directions in Psychological Science, 10(5), 173-176. https://doi.org/10.1111/1467-8721.00142

Ryba, M. M., \& Hopko, D. R. (2012). Gender differences in depression: Assessing mediational effects of overt behaviors and environmental reward through daily diary monitoring. Depression Research and Treatment, 2012, 1-9. https://doi.org/10.1155/2012/865679

Shanbhogue-Arvind, L. (2013, August 24). 5 types of conflict in literature with examples. Retrieved from http://www.booksoarus.com/types-of-conflict-literature-examples/

Siauw, B. P. (2018, June 11). Bahaya dari stigma depresi dan bunuh diri di sekitar kita. Retrieved from https://www.intothelightid.org/2018/06/11/bahaya-dari-stigma-depresidan-bunuh-diri-di-sekitar-kita/

Spierling, U. (2008). Interactive Storytelling. (N. Szilas, Ed.). Erfurt, Germany: Springer Publishing.

The Los Angeles Film School. (2017, June 9). The importance of sound. Retrieved from https://www.lafilm.edu/blog/the-importance-of-sound/ 
Sugiarto: Coda: Exploring Male Depression and the Stigma Associated with Depression

Watson, A. (2018, December 19). Film industry: Statistics \& facts. Retrieved from https://www.statista.com/topics/964/film/

World Health Organization. (2017). Depression and other common mental disorders: Global health estimates. Author. Retrieved from https://apps.who.int/iris/bitstream/handle/10665/254610/WHO-MSD-MER-2017.2eng.pdf?sequence $=1$

World Health Organization. (2020, January 30). Depression. Retrieved from https://www.who.int/news-room/fact-sheets/detail/depression 